\title{
Grape Enrichment with Zinc for Vinification: Mineral Analysis with Atomic Absorption Spectrophotometry, XRF and Tissue Analysis ${ }^{\dagger}$
}

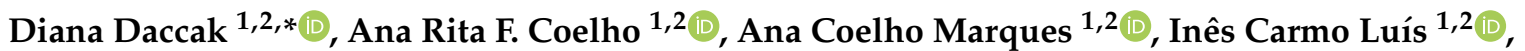 \\ Cláudia Campos Pessoa 1,2 (D), Maria Manuela Silva ${ }^{2,3}{ }^{(D)}$, Mauro Guerra ${ }^{4}$ (D), Roberta G. Leitão ${ }^{4}(\mathbb{D}$, \\ José C. Ramalho ${ }^{2,5} \mathbb{D}_{\text {, Manuela Simões }}{ }^{1,2} \mathbb{D}$, Fernando H. Reboredo ${ }^{1,2} \mathbb{D}_{\text {, Maria F. Pessoa }}{ }^{1,2} \mathbb{D}_{\text {, }}$ \\ Paulo Legoinha ${ }^{1,2}$, Paula Scotti Campos ${ }^{2,6}$ (D) Isabel P. Pais ${ }^{2,6}$ and Fernando C. Lidon ${ }^{1,2}$
}

\section{check for} updates

Citation: Daccak, D.; Coelho, A.R.F.; Marques, A.C.; Luís, I.C.; Pessoa, C.C.; Silva, M.M.; Guerra, M.; Leitão, R.G.; Ramalho, J.C.; Simões, M.; et al. Grape Enrichment with Zinc for Vinification: Mineral Analysis with Atomic Absorption Spectrophotometry, XRF and Tissue Analysis. Biol. Life Sci. Forum 2021, 4, 84. https://doi.org/ 10.3390/IECPS2020-08718

Academic Editor: Yoselin Benitez-Alfonso

Published: 1 December 2020

Publisher's Note: MDPI stays neutral with regard to jurisdictional claims in published maps and institutional affiliations.

Copyright: (c) 2020 by the authors. Licensee MDPI, Basel, Switzerland. This article is an open access article distributed under the terms and conditions of the Creative Commons Attribution (CC BY) license (https:/ / creativecommons.org/licenses/by/ $4.0 /)$.
1 Earth Sciences Department, Faculdade de Ciências e Tecnologia, Universidade Nova de Lisboa, 2829-516 Caparica, Portugal; arf.coelho@campus.fct.unl.pt (A.R.F.C.); amc.marques@campus.fct.unl.pt (A.C.M.); idc.rodrigues@campus.fct.unl.pt (I.C.L.); c.pessoa@campus.fct.unl.pt (C.C.P.); mmsr@fct.unl.pt (M.S.); fhr@fct.unl.pt (F.H.R.); mfgp@fct.unl.pt (M.F.P.); pal@fct.unl.pt (P.L.); fjl@fct.unl.pt (F.C.L.)

2 GeoBioTec Research Center, Faculdade de Ciências e Tecnologia, Universidade Nova de Lisboa, 2829-516 Caparica, Portugal; abreusilva.manuela@gmail.com (M.M.S.); cochichor@mail.telepac.pt (J.C.R.); paula.scotti@iniav.pt (P.S.C.); isabel.pais@iniav.pt (I.P.P.)

3 ESEAG/Grupo Universidade Lusófona, 1749-024 Lisboa, Portugal

4 LIBPhys-UNL, Physics Department, Faculdade de Ciências e Tecnologia, Universidade Nova de Lisboa, 2829-516 Caparica, Portugal; mguerra@fct.unl.pt (M.G.); rg.leitao@fct.unl.pt (R.G.L.)

5 PlantStress \& Biodiversity Lab, Centro de Estudos Florestais, Instituto Superior Agronomia, Universidade de Lisboa, 2784-505 Oeiras, Portugal

6 INIAV, Instituto Nacional de Investigação Agrária e Veterinária, 2780-157 Oeiras, Portugal

* Correspondence: d.daccak@campus.fct.unl.pt; Tel.: +351-212-948-573

† Presented at the 1st International Electronic Conference on Plant Science, 1-15 December 2020; Available online: https://iecps2020.sciforum.net/.

Abstract: Micronutrient deficiency affects individuals all around the world, being a public health problem. To minimize this problem, several alternatives are being developed, namely agronomic biofortification, to increase the amount of nutrients in food crops. In this context, $\mathrm{Zn}$ is one of the most relevant micronutrients for the human body, displaying catalytic, structural, and regulatory properties. Considering that Zn deficiency leads to health disorders (namely, neurological disorders, autoimmune and degenerative diseases related to age, Wilson's disease, cardiovascular problems, and diabetes mellitus), a technical itinerary for biofortification was outlined in a field of grapes located in Palmela (Portugal), aiming to optimize $\mathrm{Zn}$ content for the Syrah variety. Biofortification was performed with foliar spraying of zinc oxide $(\mathrm{ZnO})$ and zinc sulfate $\left(\mathrm{ZnSO}_{4}\right)$ throughout the production cycle (at concentrations of $0 \%, 30 \%$, and $60 \%-0,450$, and $900 \mathrm{~g} \mathrm{ha}^{-1}$ ). The zinc biofortification index increased about 59\% and 45\%, respectively, with OZn60 and SZn60 (i.e., concentrations of $60 \%$ with treatment $\mathrm{ZnO}$ and $\mathrm{ZnSO}_{4}$ respectively), whereas its deposition in the flesh of the grapes increased 2.41- and 2.37-fold and in the seeds by approx. 1.76- and 2.19-fold (with OZn60 and SZn60, respectively). After vinification, significant increases in $\mathrm{Zn}$ content in the wine were also found (1.92and 1.77-fold); however, considering the amount of this nutrient in grapes, it was concluded that vinification must also be optimized.

Keywords: biofortification; Syrah variety; wine; zinc oxide; zinc sulfate

\section{Introduction}

Micronutrient deficiencies affect more than two billion individuals worldwide and are a serious public health issue [1]. Zn is an important micronutrient in human physiology, with catalytic, structural, and regulatory properties as well as critical roles in homeostasis, 
immunologic function, oxidative stress, and the regulation of apoptosis [2,3]. Low levels of $\mathrm{Zn}$ can lead to the onset and worsening of a variety of disorders, such as neurological disorders, autoimmune and degenerative diseases related to age, Wilson's disease, cardiovascular problems, and diabetes mellitus [3]. To minimize these health problems, schedules for $\mathrm{Zn}$ biofortification of edible plants can be developed to increase the amounts of this nutrient through agronomic practices [4,5]. For agronomic biofortification, foliar application seems to stimulate more efficient capture and allocation of nutrients than soil application [5]. In 2008, the International Program HarvestPlus and its subproject HarvestZinc fueled elevated interest in increasing $\mathrm{Zn}$ in food crops by demonstrating that relative to soil fertilization, foliar application was more efficient for wheat, rice, and corn [6]. Studies in Anatólia Central and India also showed an increase in $\mathrm{Zn}$ concentrations with soil and/or foliar applications [7]. Although Portugal is not a major wine exporter, it has distinguished itself both nationally and internationally with a reputation for quality wines [8]. Moreover, some researchers have linked moderate wine consumption to health benefits associated with the prevention of cardiovascular diseases, various cancers, liver diseases, and senility [9]. Considering the physiological importance of $\mathrm{Zn}$ in the human body and the importance of wine consumption worldwide, this work aimed to increase the content of $\mathrm{Zn}$ in grapes of the Syrah variety for vinification.

\section{Experiments}

\subsection{Experimental Field}

A vineyard located in Palmela, Portugal $\left(38^{\circ} 35^{\prime} 23.629^{\prime \prime} \mathrm{N} ; 8^{\circ} 51^{\prime} 46.208^{\prime \prime} \mathrm{W}\right)$, cultivated with the Vitis vinifera L. variety Syrah and equipped with an irrigation system, was used for biofortification. The schedule for biofortification with $\mathrm{Zn}$ was implemented between 16 June and 25 September 2018. Foliar spraying was carried out with zinc sulfate $\left(\mathrm{ZnSO}_{4}\right)$ and zinc oxide $(\mathrm{ZnO})$ at concentrations of $0 \%, 30 \%$, and $60 \%\left(0,450\right.$, and $\left.900 \mathrm{~g} \mathrm{ha}^{-1}\right)$. The harvest was conducted on 11 October of 2018. During the production cycle, the weather conditions were characterized by a maximum average temperature of $28^{\circ} \mathrm{C}$ and minimum average of $16.6^{\circ} \mathrm{C}$.

\subsection{Total Soluble Solids}

Total soluble solids ( ${ }^{\circ}$ Brix) were measured in 3 randomized grape samples per treatment, using an Atago digital refractometer (Atago, Tokyo, Japan).

\subsection{Quantification of Zn in Grapes and Accumulation Level in Grape Tissues}

The zinc content in grapes was analyzed at harvest using an XRF analyzer (model XL3t $950 \mathrm{He}$ GOLDD+) under He atmosphere [10]. The grapes were cut, dried (at $60^{\circ} \mathrm{C}$, until constant weight), ground, and processed into pellets.

To map $\mathrm{Zn}$ in tissues (skin and seeds) at harvest, a Micro-energy X-ray Dispersion Fluorescence ( $\mu$-EDXRF) (M4 Tornado ${ }^{\mathrm{TM}}$, Bruker, Berlin, Germany) system was used [11]. The X-ray system was operated at $50 \mathrm{kV}$ and $100 \mu \mathrm{A}$, without application of filters, to enhance the ionization of low-Z elements. For better quantification of $\mathrm{Zn}$, a set of filters between the X-ray tube and the samples, composed of 3 foils of $\mathrm{Al} / \mathrm{Ti} / \mathrm{Cu}$ (with a thickness of 100, 50, and $25 \mu \mathrm{m}$, respectively) was further used. The measurements with filters were performed with $600 \mu \mathrm{A}$ current. Detection of fluorescence radiation was carried out with an energy-dispersive silicon drift detector, XFlash ${ }^{\mathrm{TM}}$, with $30 \mathrm{~mm}^{2}$ sensitive area and energy resolution of $142 \mathrm{eV}$ for $\mathrm{Mn} \mathrm{K} \alpha$. The measurements were made under 20 mbar vacuum conditions, and the point spectra were acquired in $200 \mathrm{~s}$.

\subsection{Zn Quantification in Wine}

The $\mathrm{Zn}$ content in wine was measured using a Perkin Elmer AAnalyst 200 atomic absorption spectrometer equipped with a deuterium background corrector and the AA WinLab software program. The wine was filtrated before analysis. 


\subsection{Statistical Analysis}

Data were statistically analyzed using one-way ANOVA $(p \leq 0.05)$ to evaluate differences. Using the results, a Tukey's test for mean comparison was performed $(95 \%$ confidence level).

\section{Results}

\subsection{Total Soluble Solids}

Total soluble solids were determined using random grape samples, and the results showed that the SZn60 application yielded higher ${ }^{\circ}$ Brix values. Relative to the control, all foliar treatments increased $\mathrm{Zn}$ content significantly, with 1.16- and 1.38-fold increases found for OZn60 and SZn60, respectively (Table 1).

Table 1. Average content \pm S.E. $(n=3)$ of ${ }^{\circ}$ Brix in fruits at harvest of Vitis vinifera L., variety Syrah. The letters $\mathrm{a}, \mathrm{b}, \mathrm{c}$ indicate significant differences of $\mathrm{Zn}$ content among treatments $(p \leq 0.05)$. Treatments OZn30, OZn60, SZn30, and SZn60 indicated the following concentrations for zinc oxide $(\mathrm{ZnO})$ or zinc sulfate $\left(\mathrm{ZnSO}_{4}\right): 0 \%, 30 \%, 60 \%$. (i.e., 0,450 , and $900 \mathrm{~g} \mathrm{ha}^{-1}$ ).

\begin{tabular}{ccc}
\hline \multirow{2}{*}{ Syrah Variety } & \multicolumn{2}{c}{ Total Soluble Solids $\left({ }^{\circ}\right.$ Brix $)$} \\
\cline { 2 - 3 } & Mean & SE \\
\hline Control & $13.10 \mathrm{c}$ & \pm 0.31 \\
OZn30 & $16.83 \mathrm{ab}$ & \pm 0.36 \\
OZn60 & $16.33 \mathrm{ab}$ & \pm 0.07 \\
SZn30 & $15.13 \mathrm{~b}$ & \pm 0.22 \\
SZn60 & $18.10 \mathrm{a}$ & \pm 0.48 \\
\hline
\end{tabular}

\subsection{Quantification of Zn in Grapes and Accumulation in the Flesh and Seeds}

Zinc content in grapes treated with $\mathrm{ZnO}$ and $\mathrm{ZnSO}_{4}$ showed significant increases compared to the control (Table 2), with the OZn60 and SZn60 foliar treatments achieving the highest increases ( $59 \%$ and $45 \%$, respectively).

Table 2. Average content \pm S.E. $(\mathrm{n}=3)$ of $\mathrm{Zn}$ in fruits at harvest of Vitis vinifera $\mathrm{L}$. variety Syrah. Different letters $(a, b)$ indicate significant differences among treatments $(p \leq 0.05)$. Treatments OZn30, $\mathrm{OZn} 60, \mathrm{SZn} 30$, and $\mathrm{SZn} 60$ indicate the following concentrations for zinc oxide $(\mathrm{ZnO})$ or zinc sulfate $\left(\mathrm{ZnSO}_{4}\right): 0 \%, 30 \%, 60 \%$. (i.e., 0,450 , and $900 \mathrm{~g} \mathrm{ha}^{-1}$ ).

\begin{tabular}{ccc}
\hline \multirow{2}{*}{ Syrah Variety } & \multicolumn{2}{c}{$\mathbf{Z n}\left(\mathbf{p p m}_{\mathbf{D w}}\right)$} \\
\cline { 2 - 3 } & Mean & SE \\
\hline Control & $13.460 \mathrm{~b}$ & \pm 0.876 \\
OZn30 & $18.843 \mathrm{ab}$ & \pm 1.799 \\
OZn60 & $21.400 \mathrm{a}$ & \pm 0.892 \\
SZn30 & $19.287 \mathrm{a}$ & \pm 1.487 \\
SZn60 & $19.580 \mathrm{a}$ & \pm 0.800 \\
\hline
\end{tabular}

At the tissue level, two regions were defined in the grapes: the grape flesh and the seeds (Table 3). Compared to the control, grape flesh showed 2.41- and 2.37-fold increases in Zn content with the OZn60 and SZn60 treatments, respectively, whereas for the seeds, 1.76- and 2.19-fold increases were measured, respectively (Table 3). Compared to the seeds, the grape flesh showed a consistently higher increase in $\mathrm{Zn}$ content. 
Table 3. Average content $(n=3)$ of $\mathrm{Zn}$ in grape flesh and seeds (after dehydration) in Syrah grapes at harvest, and the respective degree of uncertainty. Letters $a, b$ indicate significant differences in $\mathrm{Zn}$ content between treatments $(p<0.05)$. Treatments OZn30, OZn60, SZn30, and SZn60 indicate the following concentrations for zinc oxide $(\mathrm{ZnO})$ or zinc sulfate $\left(\mathrm{ZnSO}_{4}\right): 0 \%, 30 \%, 60 \%$. (i.e., 0, 450, and $\left.900 \mathrm{~g} \mathrm{ha}^{-1}\right)$.

\begin{tabular}{ccccc}
\hline \multirow{2}{*}{ Variety Syrah } & \multicolumn{2}{c}{$\begin{array}{c}\text { Grape Flesh } \\
\text { Zn (ppm }\end{array}$} & \multicolumn{2}{c}{$\begin{array}{c}\text { Seeds } \\
\text { Zn (ppm) }\end{array}$} \\
\cline { 2 - 5 } & Mean & SE & Mean & SE \\
\hline Control & $13.3 \mathrm{~b}$ & \pm 0.66 & $8.74 \mathrm{~b}$ & \pm 0.44 \\
OZn30 & $33.4 \mathrm{a}$ & \pm 1.67 & $14.8 \mathrm{ab}$ & \pm 0.74 \\
OZn60 & $32.1 \mathrm{a}$ & \pm 1.61 & $15.4 \mathrm{a}$ & \pm 0.77 \\
SZn30 & $28.0 \mathrm{a}$ & \pm 1.40 & $17.1 \mathrm{a}$ & \pm 0.85 \\
SZn60 & $31.5 \mathrm{a}$ & \pm 1.58 & $19.1 \mathrm{a}$ & \pm 0.95 \\
\hline
\end{tabular}

\subsection{Quantification of $\mathrm{Zn}$ in Wine}

$\mathrm{Zn}$-treated grapes yielded an increasing accumulation of this nutrient in the produced wine (Table 4). Spraying with OZn30 and SZn60 yielded the best responses (relative to the control, 1.92- and 1.77-fold increases, respectively).

Table 4. Average content \pm S.E. $(n=3)$ of $\mathrm{Zn}$ in monocast wine produced with Syrah grapes. Different letters $(\mathrm{a}, \mathrm{b})$ indicate significant differences $(p \leq 0.05)$. Treatments OZn30, OZn60, SZn30, and SZn60 indicate the following concentrations for zinc oxide $(\mathrm{ZnO})$ or zinc sulfate $\left(\mathrm{ZnSO}_{4}\right): 0 \%, 30 \%, 60 \%$. (i.e., 0,450 , and $900 \mathrm{~g} \mathrm{ha}^{-1}$ ).

\begin{tabular}{ccc}
\hline \multirow{2}{*}{ Syrah } & \multicolumn{2}{c}{ Zn Content in Wine $\left(\mu \mathbf{g ~ L}^{-\mathbf{1}}\right)$} \\
\cline { 2 - 3 } & Mean & SE \\
\hline Control & $0.730 \mathrm{~b}$ & \pm 0.088 \\
OZn30 & $1.398 \mathrm{a}$ & \pm 0.153 \\
OZn60 & $1.074 \mathrm{ab}$ & \pm 0.135 \\
SZn30 & $1.289 \mathrm{a}$ & \pm 0.041 \\
SZn60 & $1.295 \mathrm{a}$ & \pm 0.104 \\
\hline
\end{tabular}

\section{Discussion}

The amount of total soluble solids ( ${ }^{\circ}$ Brix) is an important parameter for vinification because it influences the final quality of the wine. Grapes must have a sufficient quantity of sugar to ensure a high fermentation rate. Indeed, insufficient time to maturation leads to watery wines with low alcohol concentration. Additionally, grapes that are harvested after the optimal time point produce a wine rich in alcohol but with low acidity [12]. Accordingly, the perfect timing for harvest depends on the country or region of production, the type of wine, and natural environmental conditions [13-15]. In this context, our data (Table 1) showed an increase of the amount of soluble solids in Zn-treated grapes, ranging between approx. 13.13-18.10 ${ }^{\circ}$ Brix, which favored our vinification process.

It has also been reported [16,17] that Zn biofortification, through soil application or foliar spraying, might affect yield parameters, grain quality, and land and water productivity. $\mathrm{ZnSO}_{4}$ is the most widely applied fertilizer due to its high solubility and low cost [18], but $\mathrm{ZnO}$ has also been shown to be effective in sunflower plants, increasing $\mathrm{Zn}$ content in all plants and improving dry weight, leaf area, and photosynthesis parameters [19]. Regarding the effectiveness of Zn enrichment in Syrah grapes, it was possible to verify that OZn60 demonstrated better results (compared to SZn60). Moreover, Zn accumulation prevailed in the flesh of the grapes, surpassing 30\% compared to the control, thus revealing the effectiveness of biofortification [20,21]. Indeed, a higher biofortification index was achieved (Table 3).

In general, Portuguese wines have low amounts of $\mathrm{Zn}$ (between $0.16-1.96 \mathrm{mg} \mathrm{L}^{-1}$ ) [22]. Similarly to other metals, the amount of $\mathrm{Zn}$ in wines depends on the intensity of maceration, 
extraction, and solubilization during fermentation because $\mathrm{Zn}$ is preferentially concentrated in the grape peel and seeds [22]. Comparing the content of $\mathrm{Zn}$ in grapes and wine, significant losses occurred during vinification, which indicates that this process requires optimization. Nevertheless, a significant yield of $\mathrm{Zn}$ was obtained in the produced wine.

\section{Conclusions}

Biofortification with $\mathrm{Zn}$ in Syrah grapes increases the total soluble solids, but additional assays should be performed when climatic conditions have a stronger influence on the content.

Biofortification in general proved to be effective in increasing the $\mathrm{Zn}$ content of grapes and wine, and OZn yielded the best results, but the vinification process itself needs to be optimized.

Supplementary Materials: The poster presentation is available online at https:/ /www.mdpi.com/ article/10.3390/IECPS2020-08718/s1.

Author Contributions: M.G., J.C.R., P.S.C. and F.C.L. conceived and designed the experiments; C.C.P., A.R.F.C., A.C.M., I.C.L., D.D., P.S.C. and I.P.P. performed the experiments; C.C.P., P.S.C., I.P.P. and F.C.L. analyzed the data; M.M.S., M.G., R.G.L., M.S., J.C.R., F.H.R., M.F.P., P.S.C., I.P.P., P.L. and F.C.L. contributed reagents/materials/analysis tools; D.D. and F.C.L. wrote the paper. All authors have read and agreed to the published version of the manuscript.

Acknowledgments: The authors thank Engenier Luís Silva (Adega Cooperativa de Palmela- Casa Agrícola Nunes Oliveira da Silva Lda) for technical assistance to project PDR2020-101-030727_for the financial support. We also extend our thanks to the Research centres (GeoBioTec) UIDB/04035/2020. This work was further supported in part by the research center Grant $N^{\circ}$. UID/FIS/04559/2013 to LIBPhys-UNL, from the FCT/MCTES/PIDDAC and by the project PDR2020-101-030727.

Conflicts of Interest: The authors declare no conflict of interest. The founding sponsors had no role in the design of the study; in the collection, analyses, or interpretation of data; in the writing of the manuscript; or in the decision to publish the results.
Abbreviations
OZn10 Foliar application of zinc oxide with a concentration of $10 \%\left(150 \mathrm{~g} \mathrm{ha}^{-1}\right)$
OZn 30 Foliar application of zinc oxide with a concentration of $30 \%\left(450 \mathrm{~g} \mathrm{ha}^{-1}\right)$
OZn60 Foliar application of zinc oxide with a concentration of $60 \%\left(900 \mathrm{~g} \mathrm{ha}^{-1}\right)$
SZn10 Foliar application of zinc sulfate with a concentration of $10 \%\left(150 \mathrm{~g} \mathrm{ha}^{-1}\right)$
SZn30 Foliar application of zinc sulfate with a concentration of 30\% (450 $\left.\mathrm{g} \mathrm{ha}^{-1}\right)$
SZn60 Foliar application of zinc sulfate with a concentration of $60 \%\left(900 \mathrm{~g} \mathrm{ha}^{-1}\right)$

\section{References}

1. Bouis, H.E.; Saltzman, A. Improving nutrition through biofortification: A review of evidence from HarvestPlus, 2003 through 2016. Glob. Food Sec. 2017, 12, 49-58. [CrossRef] [PubMed]

2. Liu, D.; Liu, Y.; Zhang, W.; Chen, X.; Zou, C. Agronomic Approach of Zinc Biofortification Can Increase Zinc Bioavailability in Wheat Flour and thereby Reduce Zinc Deficiency in Humans. Nutrients 2017, 9, 465. [CrossRef] [PubMed]

3. Chasapis, C.T.; Loutsidou, A.C.; Spiliopoulou, C.A.; Srefanidou, M.E. Zinc and human health: An update. Arch. Toxicol. 2011, 86, 521-534. [CrossRef] [PubMed]

4. World Health Organization. Available online: https://www.who.int/elena/titles/bbc/biofortification/en/ (accessed on 20 October 2020).

5. Valença, A.W.; Bake, A.; Brouwer, I.D.; Giller, K.E. Agronomic biofortification of crops to fight hidden hunger in sub-Saharan Africa. Glob. Food Sec. 2017, 12, 8-14. [CrossRef]

6. Cakmak, I.; Kutman, U.B. Agronomic biofortification of cereals with zinc: A review. Eur. J. Soil Sci. 2017, 69, 172-180. [CrossRef]

7. Roohani, N.; Hurrel, R.; Kelishadi, R.; Schulin, R. Zinc and its importance for human health: An integrative review. J. Res. Med. Sci. 2013, 18, 144-157. [PubMed]

8. Rosado, A.R.D.S. Evolução de Parâmetros Físicos, Químicos e Controlo Microbiológico em Vinhos Brancos e Tintos da Adega Cooperativa de Palmela. Master's Thesis, Universidade Nova de Lisboa- Faculdade de Ciências e Tecnologias, Monte da Caparica, Portugal, 2013.

9. Penna, N.G.; Hecktheuer, L.H.R. Vinho e Saúde: Uma revisão. Infarma 2004, 16, 64-67. 
10. Pelica, J.; Barbosa, S.; Lidon, F.; Pessoa, M.F.; Reboredo, F.; Calvão, T. The paradigm of high concentration of metals of natural or anthropogenic origin in soils-The case of Neves-Corvo mine area (Southern Portugal). J. Geochem. Explor. 2018, 186, 12-23. [CrossRef]

11. Cardoso, P.; Velu, G.; Singh, R.P.; Santos, J.P.; Carvalho, M.L.; Lourenço, V.M.; Lidon, F.C.; Reboredo, F.; Guerra, M. Localization and distribution of $\mathrm{Zn}$ and Fe in grains of biofortified bread wheat lines through micro- and triaxial- X-ray fluorescence spectrometry. Spectrochim. Acta Part B At. Spectrosc. 2018, 141, 70-79. [CrossRef]

12. Lins, A.D.F.; Roque, I.M.B.; Lisbôa, C.G.C.; Feitosa, R.M.; Costa, J.D.S. Qualidade durante o desenvolvimento de uvas viníferas 'Syrah' do Submédio do Vale São Francisco. AGROTEC 2015, 36, 259-263, ISSN 0100-7467.

13. Favero, A.C. Viabilidade de Produção da Videira 'Syrah', em Ciclos de Verão e Inverno no sul de Minas Gerais. Master's Thesis, Universidade Federal de Lavras, Minas Gerais, Brasil, 2007.

14. Junior, M.J.P.; Hernandes, J.-L.; Camparott, L.B.; Blain, G.C. Plant parameters and must composition of 'Syrah' grapevine cultivated under sequential summer and winter growing seasons. Bragantia 2017, 76, 345-351. [CrossRef]

15. Santos, A.O.; Hernandes, J.L.; Júnior, P.M.J.; Rolim, G.S. Parâmetros fiotécnicos e condições microclimáticas para videira vinífera conduzida sob dupla poda sequencial. Rev. Bras. Eng. Agrícola Ambient. 2011, 15, 1251-1256. [CrossRef]

16. Bhatt, R.; Hossain, A.; Sharma, P. Zinc biofortification as an innovative technology to alleviate the zinc deficiency in human health: A review. Open Agric. 2020, 5, 176-187. [CrossRef]

17. Shivay, Y.S.; Prasad, R.; Rahal, A. Relative efficiency of zinc oxide and zinc sulphate-enriched urea for spring wheat. Nutr. Cycl. Agroecosyst. 2008, 82, 259-264. [CrossRef]

18. Cakmak, I. Enrichment of cereal grains with zinc: Agronomic or genetic biofortification? Plant Soil 2008, 302, 1-17. [CrossRef]

19. Torabian, S.; Zahedi, M.; Khoshgoftar, A.H. Effects of foliar spray of two kinds of zinc oxide on the growth and ion concentration of sunflower cultivars under salt stress. J. Plant Nutr. 2016, 39, 172-180. [CrossRef]

20. Gonçalves, A.S.F.; Pinho, R.G.V.; Guilherme, L.R.G.; Furtado, J.E.B.; Pereira, F.C. Foliar feeding with zinc as a biofortification strategy in maize. RBMS 2019, 18, 281-289. [CrossRef]

21. Yilmaz, A.; Ekiz, H.; Torun, B.; Gultekin, I.; Karanlik, S.; Bagci, S.A.; Cakmak, I. Effect of different zinc application methods on grain yield and zinc concentration in wheat cultivars grown on zinc-deficient calcareous soils. J. Plant Nutr. 1997, $20,461-471$. [CrossRef]

22. Catarino, S.; Curvelo-Garcia, A.S.; Sousa, R.B. Determinação do Zinco em Vinhos por Espectrofotometria de Absorção Atómica com Chama. Ciência Técnica Vitivinícola 2002, 17, 15-26. 